\title{
Endobronchial Lymphoma: A Case Report
}

\section{Endobronşiyal Lenfoma: Olgu Sunumu}

Hüseyin Fatih Sezer ${ }^{1}$, Aykut Eliçora', Tuba Çiftçi Küsbeci² ${ }^{2}$ Salih Küçük³, Fuad Pasiyev ${ }^{4}$ Demir Kursat Yıldız ${ }^{5}$, Çiğdem Vural ${ }^{6}$, Umay Kiraz ${ }^{6}$, Ahmet Ilgazlı

\begin{abstract}
Non-Hodgkin lymphomas are tumors that develop in lymphoid tissue, and mainly in the lymph nodes. Although tracheobronchial invasion is rare in NonHodgkin lymphomas, it has been reported in $3.6 \%$ of patients with extranodal lymphoma. We present here our experience of a tumor identified as an atypical cause of chest pain that led to a total atelectasis by obstructing the right main bronchus with endobronchial invasion, diagnosed with bronchoscopic biopsy.
\end{abstract}

Key words: Endobronchial Lymphoma, Non-Hodgkin Lymphoma, bronchoscopy.

\section{Özet}

Non-Hodgkin lenfomalar lenfoid dokulardan, esas olarak lenf düğümlerinden kaynaklanan tümörlerdir. Non-Hodgkin lenfomalarda trakeobronşiyal tutulum nadir olmakla birlikte ekstranodal lenfomalı hastalarda \%3,6 oranında trakeobronşiyal tutulum bildirilmiştir. Çalışmamızda göğüs ağrısının atipik bir sebebi olarak saptadığımız, endobronşiyal tutulumu sağ ana bronşu tümüyle obstrükte ederek total atelektaziye yol açan ve bronkoskopik biyopsi ile tanı alan tümör olgusundaki deneyimimizi sunmayı amaçladık.

Anahtar Sözcükler: Endobronşiyal Lenfoma, NonHodgkin Lenfoma, bronkoskopi.
'Department of Thoracic Surgery, Kocaeli University, Kocaeli,

Turkey

${ }^{2}$ Yozgat City Hospital, Yozgat, Turkey

${ }^{3}$ Kocaeli State Hospital, Kocaeli, Turkey

${ }^{4}$ Private İstanbul Regional Hospital, İstanbul, Turkey

${ }^{5}$ Memorial Bahçelievler Hospital, İstanbul, Turkey

${ }^{6}$ Department of Pathology, Kocaeli University, Kocaeli, Turkey

${ }^{7}$ Department of Pulmonology, Kocaeli University, Kocaeli, Turkey

\author{
'Kocaeli Üniversitesi Tıp Fakültesi, Göğüs Cerrahisi Anabilim \\ Dalı, Kocaeli \\ ${ }^{2}$ Yozgat Şehir Hastanesi, Yozgat \\ ${ }^{3}$ Kocaeli Devlet Hastanesi, Kocaeli \\ ${ }^{4}$ Özel İstanbul Bölge Hastanesi, İstanbul \\ ${ }^{5}$ Memorial Bahçelievler Hastanesi, İstanbul \\ ${ }^{6}$ Kocaeli Üniversitesi Tıp Fakültesi, Patoloji Anabilim Dalı, \\ Kocaeli \\ ${ }^{7}$ Kocaeli Üniversitesi Tıp Fakültesi, Göğüs Hastalıkları Ana- \\ bilim Dalı, Kocaeli
}

Submitted (Başvuru tarihi): 17.10.2020 Accepted (Kabul tarihi): 10.12.2020

Correspondence (iletişim): Hüseyin Fatih Sezer, Department of Thoracic Surgery, Kocaeli University, Kocaeli, Turkey

e-mail: hfs.hfs@gmail.com 
Non-Hodgkin lymphoma (NHL) is a heterogeneous neoplasm that can involve any part of the body $(1,2)$. Extranodal lymphomas account for $24-48 \%$ of NHLs (3). Although extranodal lymphomas can be seen in any organ, they are most frequently seen in the gastrointestinal system, Waldeyer ring and tonsils, while bronchial tree invasion is rare $(4,5)$. Tracheobronchial involvement has been reported at a rate of $3.6 \%$ in studies (6). The first case of endobronchial NHL (ENHL) was described by Dawe et al. in 1955. (7).

There have been no studies to date involving a large number of patients assessing the clinical features, diagnosis and treatment of ENHL cases, with most studies to date being in the form of individual case reports $(2,3,6,8)$. ENHL can simulate primary lung malignancies radiologically and clinically, and for this reason, it is important that the patient be diagnosed in good time, allowing a treatment approach to be determined earlier, and to avoid any waste of time on unnecessary tests and procedures. Bronchoscopic procedures can be used for diagnostic purposes.

\section{CASE}

A 33-year-old male patient with no previous symptoms was admitted to the emergency department with chest pain, short-distance effort dyspnea and hemoptysis that had started within the last 10 days. The patient had no complaints of fever, weight loss or night sweats; and there was no history of smoking, substance use or occupational exposure.

Vital signs were stable. A physical examination revealed the right hemithorax to be less involved in breathing, mild dullness in the right hemithorax, and decreased lung sounds in the middle and lower parts of the right hemithorax on auscultation.

No pathological value was found in blood tests (biochemistry, hemogram, coagulometric, arterial blood gasses).

PA chest radiograph revealed the trachea, heart and mediastinum to be deviated to the right side, and the right hemithorax to be almost completely opaque (Figure la).

A thorax computed tomography (CT) revealed a mass lesion in the right lung measuring $5 \times 3 \mathrm{~cm}$ that was invasive to the right pulmonary artery and obstructing the right main bronchus. No hilar or mediastinal lymphadenopathy was observed (Figure $1 \mathrm{~b}$ and $\mathrm{c}$ ).
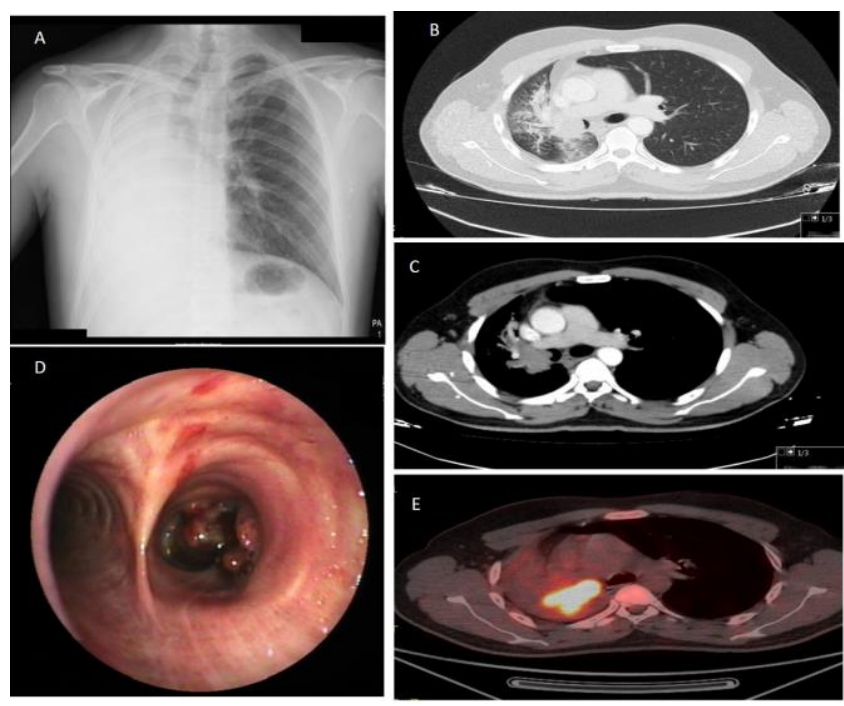

Figure 1a, b, c, $d$ and e: Chest x-ray (a), thorax CT scans $(b, c)$, bronchoscopic view of the tumor (d), PET-CT scans (e)

Positron Emission Tomography (PET-CT) revealed a central mass on the right lung (SUVmax: 41.5), a nodule in the posterobasal segment of the left lung (SUVmax: 12.2), suspicious lymphadenopathies in terms of metastasis in the mediastinum. There was an appearance compatible with soft tissue metastases in the $\mathrm{L} 1$ vertebra and the right 11 th intercostal space, and bone metastases in the T12 and S1 vertebrae (Figure 1e).

A fiberoptic bronchoscopic (FOB) examination revealed an endobronchial lesion with a tendency to hemorrhage at the entrance of the right main bronchus that prevented distal transition (Figure 1d). A sample was taken from the lesion for cytological examination by needle aspiration during the procedure, but no definite histopathological diagnosis could be determined. Rigid bronchoscopy was performed, biopsies were taken with a tumoral punch and transbronchial needle aspiration, and the samples were examined histopathologically and immunohistochemically. Bronchoscopic biopsy was reported as NHL (NK/T Cell Lymphoma, CD3+/CD56+/CD68+/EMA+) (Figure 2). The patient was started on a chemotherapy protocol (Cyclophosphamide, Hydroxydaunorubicin, Oncovin, Etoposide, Prednisone: $\mathrm{CHOEP}$, and the symptoms disappeared in the 3rd week of treatment. A PA chest radiograph taken in the second month of the treatment revealed that the lesion had regressed, as well as the mediastinal shift, and the opaque appearance in the right hemithorax had disappeared almost completely (Figure 3). The patient continues to be followed up without any problems. 


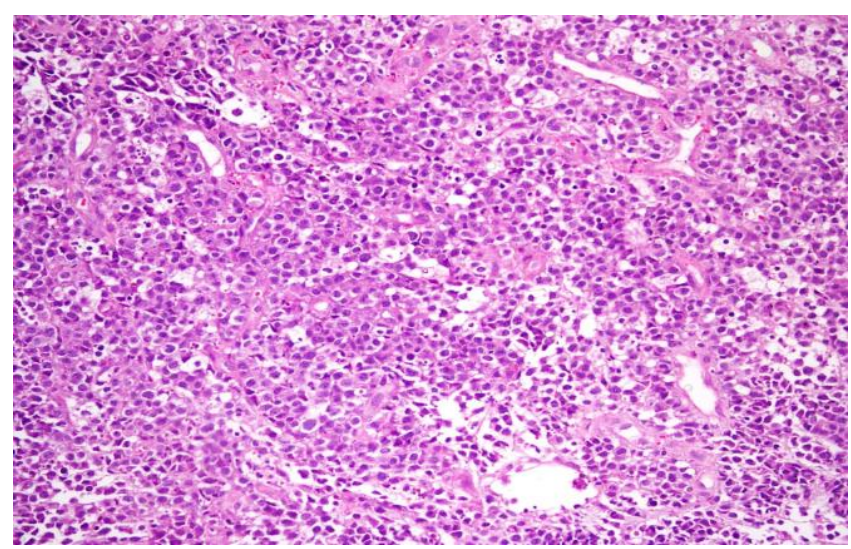

Figure 2: Diffuse, medium-sized atypical lymphoid cell infiltration (H\&E x 200)

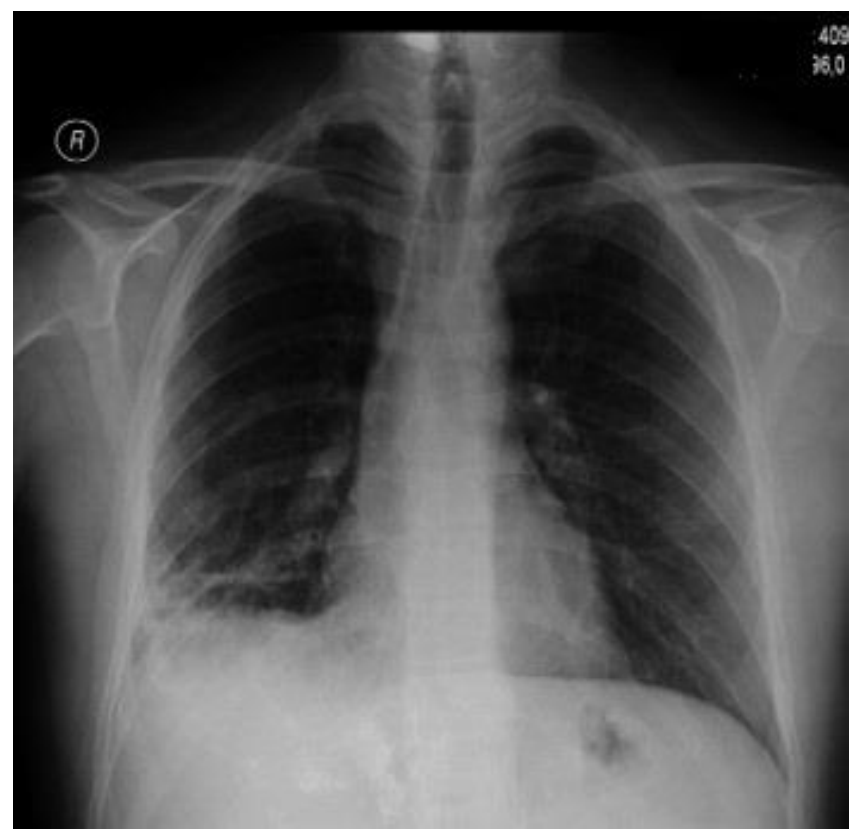

Figure 3: Second month chest $x$-ray

\section{DISCUSSION}

The frequency of endobronchial invasion of NHLs is low (4-6). In an autopsy study of $55 \mathrm{NHL}$ patients, no endobronchial lymphoma was observed in any of the cases (9). The incidence of ENHL is primarily in the main bronchi, lobe bronchi and trachea (10).

Often clinical in NHL are B symptoms (fever, night sweats, weight loss), loss of appetite, lymphadenopathy, especially in the cervical, axillary and inguinal region (8). Our patient had no such complaints, but rather effort dyspnea and hemoptysis. In the review report of Eng et al. (11), 31 ENHL case reports were examined in which ENHL was found more frequently in the endobronchial main branches. The authors reported that different degrees of lobar collapse were observed in chest radiography and thorax CT in half of their series. In our case, prominent lobar collapse was identified in the right hemithorax.
Bronchoscopic biopsy should be performed for a diagnosis of ENHL. The advantages of FOB are fewer operation procedures and less invasiveness, while those of rigid bronchoscopy include airway safety, equipment richness, large tissue sampling and the ability to perform FOB inside the canal $(12,13)$. Clinicians should choose their own method. Rigid bronchoscopy was performed on our patient to obtain larger tissue samples after needle aspiration and lavage fluid from a vascularized tumor with FOB were not diagnostic. As a result of histopathological and immunohistochemical analysis of the samples, a diagnosis of $\mathrm{NHL}$ was obtained.

Treatment success and life span in NHL is significantly higher (14). Only chemotherapy, immunotherapy, radiotherapy, alone, or in combination, is used for treatment (15). In our case, a significant clinical and radiological response was obtained as a result of CHOEP chemotherapy. The case has been followed for 4 years, and is in clinical and radiological remission.

\section{CONCLUSION}

In patients with suspected lung cancer, lymphoid malignancies should always be kept in mind in differential diagnosis due to the distinct differences in treatment approach and prognosis.

\section{CONFLICTS OF INTEREST}

None declared.

\section{AUTHOR CONTRIBUTIONS}

Concept - H.F.S., A.E., T.Ç.K., S.K., F.P., D.K.Y., Ç.V., U.K., A.I.; Planning and Design - H.F.S., A.E., T.Ç.K., S.K., F.P., D.K.Y., Ç.V., U.K., A.I.; Supervision - H.F.S., A.E., T.Ç.K., S.K., F.P., D.K.Y., Ç.V., U.K., A.I.; Funding H.F.S., A.E., T.Ç.K., S.K., F.P., D.K.Y., Ç.V., U.K., A.I.; Materials - H.F.S., A.E., T.Ç.K., S.K., F.P., D.K.Y., Ç.V., U.K., A.I.; Data Collection and/or Processing - H.F.S., A.E., T.Ç.K., S.K., F.P., D.K.Y., Ç.V., U.K., A.I.; Analysis and/or Interpretation - H.F.S., A.E., T.Ç.K., S.K., F.P., D.K.Y., Ç.V., U.K., A.I.; Literature Review - H.F.S., A.E., T.Ç.K., S.K., F.P., D.K.Y., Ç.V., U.K., A.I.; Writing H.F.S., A.E., T.Ç.K., S.K., F.P., D.K.Y., Ç.V., U.K., A.I.; Critical Review - H.F.S., A.E., T.Ç.K., S.K., F.P., D.K.Y., Ç.V., U.K., A.I.

\section{YAZAR KATKILARI}

Fikir - H.F.S., A.E., T.Ç.K., S.K., F.P., D.K.Y., Ç.V., U.K., A.I.; Tasarım ve Dizayn - H.F.S., A.E., T.Ç.K., S.K., F.P., D.K.Y., Ç.V., U.K., A.I.; Denetleme - H.F.S., A.E., T.Ç.K., 
S.K., F.P., D.K.Y., Ç.V., U.K., A.I.; Kaynaklar - H.F.S., A.E., T.Ç.K., S.K., F.P., D.K.Y., Ç.V., U.K., A.I.; Malzemeler - H.F.S., A.E., T.Ç.K., S.K., F.P., D.K.Y., Ç.V., U.K., A.I.; Veri Toplama ve/veya İşleme - H.F.S., A.E., T.Ç.K., S.K., F.P., D.K.Y., Ç.V., U.K., A.I.; Analiz ve/veya Yorum - H.F.S., A.E., T.Ç.K., S.K., F.P., D.K.Y., Ç.V., U.K., A.I.; Literatür Taraması - H.F.S., A.E., T.Ç.K., S.K., F.P., D.K.Y., Ç.V., U.K., A.I.; Yazıyı Yazan - H.F.S., A.E., T.Ç.K., S.K., F.P., D.K.Y., Ç.V., U.K., A.I.; Eleştirel Inceleme - H.F.S., A.E., T.Ç.K., S.K., F.P., D.K.Y., Ç.V., U.K., A.I.

\section{REFERENCES}

1. Dehghani M, Haddadi S, Vojdani R. Signs, symptoms and complications of non-Hodgkin's lymphoma according to grade and stage in South Iran. Asian Pac J Cancer Prev 2015; 16:3551-7. [CrossRef]

2. Argüder E, Hasanoğlu HC, Karalezli A, Aknc S, Dilek I. Endobronchial involvement in non-Hodgkin lymphoma. J Bronchology Interv Pulmonol 2012; 19:142-4. [CrossRef]

3. d'Amore F, Christensen BE, Brincker H, Pedersen NT, Thorling K, Hastrup J, et al. Clinicopathological features and prognostic factors in extranodal non-Hodgkin lymphomas. Danish LYFO Study Group. Eur J Cancer 1991; 27:1201-8. [CrossRef]

4. Economopoulos T, Asprou N, Stathakis N, Papageorgiou E, Dervenoulas J, Xanthaki K, et al. Primary extranodal nonHodgkin's lymphoma in adults: clinicopathological and survival characteristics. Leuk Lymphoma 1996; 21:131-36. [CrossRef]

5. Economopoulos T, Papageorgiou S, Rontogianni D, Kaloutsi V, Fountzilas G, Tsatalas $C$, et al. Multifocal extranodal non-Hodgkin lymphoma: a clinicopathologic study of 37 cases in Greece, a Hellenic Cooperative Oncology Group study. Oncologist 2005; 10:734-8. [CrossRef]

6. Gasparetto TD, Azevedo FB, Toledo A, Zanetti G, Marchiori E. Primary tracheal non-Hodgkin lymphoma: case report with an emphasis on computed tomography findings. J Thorac Imaging 2010; 25:W24-6. [CrossRef]

7. Dawe CJ, Woolner LB, Parkhill EM, McDonald JR. Cytologic studies of sputum, secretions and serous fluids in malignant lymphoma. Am J Clin Pathol 1955; 25:480-8. [CrossRef]

8. Solomonov A, Zuckerman T, Goralnik L, Ben-Arieh Y, Rowe JM, Yigla M. Non-Hodgkin's lymphoma presenting as an endobronchial tumor: Report of eight cases and literature review. Am J Hematol 2008: 83:416-9. [CrossRef]

9. Vieta JO, Cravor LF. Intrathoracic manifestations of the lymphomatoid diseases. Radiology 1941; 37:138-59. [CrossRef]

10. Pajares V, Torrego A, Granell M, Szafranska M, Mozos A Puzo C. Recurrent endobronchial diffuse large B-cell lymphoma. Diagnosed by Cryoprobe. Arch Bronconeumol 2013; 49:210-2. [CrossRef]

11. Eng J, Sabanathan S. Endobronchial non-Hodgkin's lymphoma. J Cardiovasc Surg (Torino) 1993; 34:351-4.

12. Akpınar S, Yazıcı Ü. Fiberoptik Bronkoskopi. In: Özkan S ed. Emergency Situations and Basic Manipulation Techniques in Thoracic Surgery. Ankara: Derman Tibbi Yayıncılık; 2015:108-18.

13. Sezer HF, Çolak B, Topçu S, Avcı A, Abdullayev G. Çocuklarda yabancı cisim aspirasyonlarına klinik yaklaşım ve hukuki sonuçları. Tuberk Toraks 2019; 67:13641. [CrossRef]

14. Survival Rates and Factors That Affect Prognosis for NonHodgkin Lymphoma. American Cancer Society 2020. https://www.cancer.org/cancer/non-hodgkinlymphoma/detection-diagnosis-staging/factorsprognosis.html.

15. Ansell SM. Non-Hodgkin lymphoma: diagnosis and treatment. Mayo Clin Proc 2015; 90:1 152-63. [CrossRef] 